\title{
THE YOUNG PEOPLE'S PERCEPTION ON THE NEED OF AN ACTIVE LIFE THROUGH REGULAR SPORT ACTIVITIES
}

Marius VAIDA ${ }^{1}$

\begin{abstract}
This study had the main purpose of emphasising the level of perception of today's youth on the physical exercise in general, with extensions on social involvement as well, on some of their effects, but also to clarify certain problems which are not understood for what they are worth by the young people. This study was undertaken at the Petroleum-Gas University of Ploiesti on a group of 100 students (boys and girls) aged between 19 and 29, having as main research method the survey, based on a standardized questionnaire. The latter was anonymous, it had 8 items, being a questionnaire with a single choice out of three or more possible answers. The undertaken research reveals that by practicing different sport activities they had met new people, highlighting the socialization factor of the researched phenomenon. In the same context, practicing sports is important for the personal development of young people, having a conciliatory role in certain conflicts, and overcoming social barriers. At the same time, we note that sports activity is important in everyday life for young people, but the most of them do not regularly follow sports events (on TV or live). Regardless of how physical activity is practiced, life without physical exercise should not exist, the benefits of these activities being far beyond certain inconveniences such as the time spent in such activities (more correctly the lack of necessary time), certain physical discomforts (muscle soreness), the possibility of injuries or even lack of interest.
\end{abstract}

Keywords: perception; sport activity; regular; active life; young people's

JEL classification: I0, I19

DOI: $10.24818 / \mathrm{mrt}$.20.11.02.04

\section{Introduction}

Physical activity / sport is one of the issues discussed in modern society, these phenomena being, at the level of young people, even a problem of their perception, as understanding the importance of physical activity and sport is in general essential for maintaining the health of the young population and not only.

\footnotetext{
${ }^{1}$ Petroleum and Gas University of Ploieşti, Romania, E-mail: vaidamarius@yahoo.com
} 
Nowadays, knowledge of physical condition is a very important element, because it cannot be maintained or developed unless we know exactly the starting point and where we want to be, this being an important principle in the dynamics of the phenomenon, namely the framework for evaluating the performance of this activity. Within physical condition we can include certain biological factors and even some mental processes.

Regular physical activity is considered one of the main factors in maintaining the individual's optimum wellness. This activity has numerous benefits, such as: it strengthens health, it achieves a harmonious physical development, it improves the functioning of various systems and functions of the body (cardiovascular, respiratory, nervous, etc.), it improves the various components of the physical condition (speed, strength, endurance, coordination, joint mobility, muscle elasticity), it has positive effects on socio-professional integration, it develops affective abilities (will, reactions, perseverance, positive feelings etc.), it develops cognitive abilities (analysis, synthesis, etc.), it develops psychomotor skills (motor reactions, automatisms, etc.), it extends the sphere of motor skills (basic and utilitarian-applicative), it prevents and even correct certain deficient attitudes, etc.

As it is known, the effects of a sedentary lifestyle are not to be neglected, and it predisposes the individual to myocardial infarction, obesity, diabetes, atherosclerosis, constipation, functional disorders, stroke, etc., all of which should make the individual think and evaluate his/her own actual lifestyle.

By practicing regularly a sport it may be observed that individuals have a greater amount of energy, are more relaxed and, last but not least, are happier. From the point of view of the couple's relationship, we can say that it is strengthened by this type of activity, as this common hobby drives individuals closer to each other.

In the same context, having a job where sitting all day on a chair can translate at physiological level by slowing blood flow to certain parts of the body, metabolic changes, etc. Even for those who have a job of this type there are solutions through short periodic active breaks in which they should get stretching exercises, climbing and descending stairs, walking etc.

Concerning young adulthood between 18-20 and 30 years old, C. Bota (2000, p. 288-289) emphasises that "for the untrained adult it can be described as a period with a relative preservation of the motor performance capacity - of course there may be a regression, especially in the motor-speed quality. For the trained athlete it is the period of the highest sports performance, except for some sports (eg swimming, gymnastics)”. The same author (C. Bota, 2000, p. 289) reminds that "the average adult age is in this classification between $30-50$ years old. It is the age of progressive diminution of motor performance. Untrained subjects demonstrate a decrease in performance, particularly in the field of coordination, but also in speed and endurance; the strength is still relatively well preserved. In trained subjects, this average age is a period of performance maintenance.” We presented these 
because the present study refers to a specific group age of young adults, that may be extrapolated to the average adult age.

\section{Research purpose and objectives}

This study had the main purpose of emphasising the level of perception of today's youth on the physical exercise / sport in general, with extensions on social involvement as well, on some of their effects, and also to clarify certain problems which are not understood for what they are worth by the young people.

The study objectives are: estimating the level of perception of an active life effects; discovering the main reason for which young people today participate in sports activities; observing the importance of an active lifestyle to them; analysis of factors related to personal development from the perspective of practicing certain sports activities; understanding the conciliatory role that sport activities have on different conflicts.

\section{Research methods}

This study was undertaken at the Petroleum-Gas University of Ploiesti on a sample of 100 students (boys and girls) aged between 19 and 29, having as main research method the survey, based on a standardized questionnaire. The latter was anonymous, it had 8 items, being a questionnaire with a single choice out of 3 or more possible answers. Among the other methods of research which were used are: the method of bibliographic study, of processing statistical data and the graphic method.

The items used in this questionnaire are presented below, both in a form of a graph and as values, accompanied by the appropriate discussions on each item.

\section{Results and discussion}

By processing the questionnaires, the results obtained in item 1 "Do you consider sport as an important aspect in daily life?" are presented in Table 1 as number and percentage, but also in figure 1 as percentage.

Table 1. Values resulted from the processing of item 1

\begin{tabular}{|c|l|l|l|l|l|l|l|l|l|l|}
\hline \multirow{3}{*}{$\begin{array}{c}\text { Item } \\
1 .\end{array}$} & \multicolumn{2}{|l|}{$\begin{array}{l}\text { Very } \\
\text { important }\end{array}$} & \multicolumn{2}{|l|}{ Important } & \multicolumn{2}{l|}{ Unimportant } & \multicolumn{2}{l|}{$\begin{array}{l}\text { I do not } \\
\text { know }\end{array}$} & \multicolumn{2}{|l|}{ Total } \\
\cline { 2 - 11 } & No. & $\%$ & No. & $\%$ & No. & $\%$ & No. & $\%$ & No. & $\%$ \\
\cline { 2 - 12 } & 20 & 20 & 48 & 48 & 19 & 19 & 13 & 13 & 100 & 100 \\
\hline
\end{tabular}




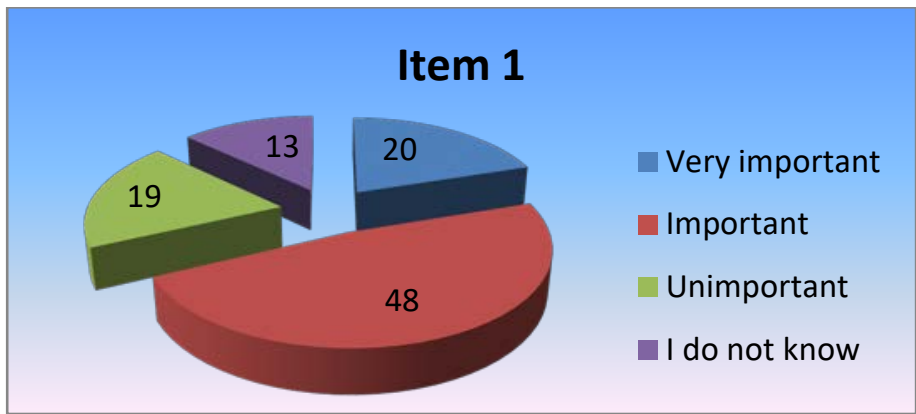

Graph 1. The percentage values of the data item 1

From the data we can see that $48 \%$ of the responses were that sport is important in daily life, $20 \%$ answered that it is very important in everyday life, $19 \%$ of students think it is irrelevant and only $13 \%$ did not know what to answer. By doing the sum of the first two results, we observe a value of $68 \%$ of the total of responses, emphasising that young people regard sport as being important or very important to them. These results are confirmed of another study undertaken on a similar sample of university students Studies (Pop, 2014).

Item 2 answers the question: "Do you think that sport can overcome social difficulties / barriers?" The answers are presented below, the possibility of choosing them is yes, no or I do not know.

Table 2. Values resulted from the processing of item 2

\begin{tabular}{|c|c|c|c|c|c|c|c|c|}
\hline \multirow{2}{*}{$\begin{array}{c}\text { Item } \\
2 .\end{array}$} & \multicolumn{2}{|c|}{ Yes } & \multicolumn{2}{c|}{ No } & \multicolumn{2}{c|}{ I do not know } & \multicolumn{2}{c|}{ Total } \\
\cline { 2 - 9 } & No. & $\%$ & No. & $\%$ & No. & $\%$ & No. & $\%$ \\
\cline { 2 - 9 } & 67 & 67 & 12 & 12 & 21 & 21 & 100 & 100 \\
\hline
\end{tabular}

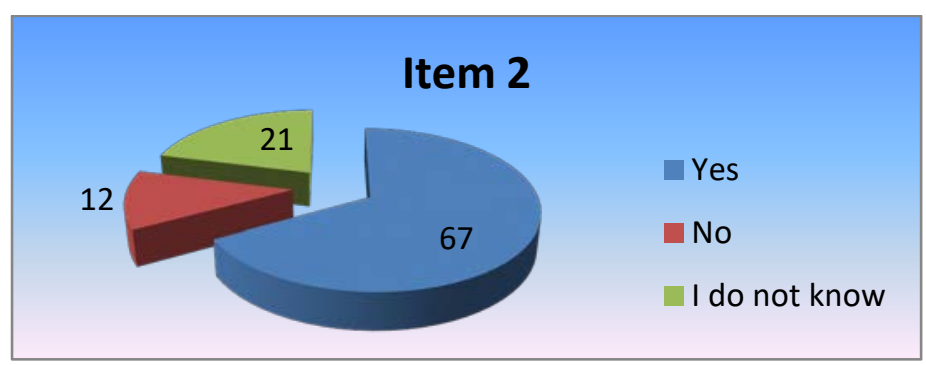

Graph 2. The percentage values of the data item 2

Most of the subjects surveyed think that sport exceeds social barriers, the percentage $67 \%$ being well above the other answers. At the same time, the negative answers were only $12 \%$ and those that corresponded to the "I do not know" answer were $21 \%$. 
Item 3 is represented by the question: "Do you regularly watch sports events (on TV or live)?". As in the previous item, the results obtained are presented in Table 3 as number and percentage and in figure 3 only under the form of percentage.

Table 3. Values item 3

\begin{tabular}{|c|l|l|l|l|l|l|}
\hline \multirow{2}{*}{$\begin{array}{c}\text { Item } \\
3 .\end{array}$} & Yes & No. & $\%$ & No & $\%$ & Total \\
\cline { 2 - 7 } & 41 & 41 & 59 & 59 & 100 & 100 \\
\hline
\end{tabular}

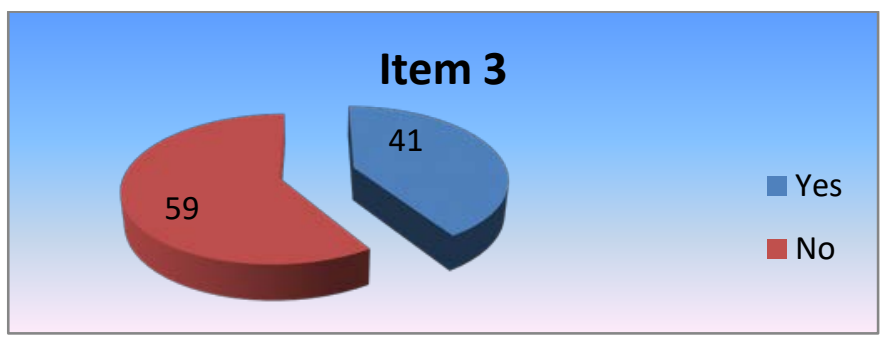

Graph 3. The percentage values of the data item 3

The results obtained in this item are very clear, the great majority of today's young people do not regularly follow sport events, with $59 \%$ negative answers as compared to the positive ones, which have a value of only $41 \%$.

Item 4 corresponds to the question "Do you think that physical activity / sport has a conciliatory role in certain conflicts?" and it has the answers processed in percentage as follows:

Table 4. Values of item 4

\begin{tabular}{|c|c|c|c|c|c|c|c|c|}
\hline \multirow{2}{*}{$\begin{array}{c}\text { Item } \\
4 .\end{array}$} & \multicolumn{2}{|c|}{ Yes } & \multicolumn{2}{|c|}{ No } & \multicolumn{2}{c|}{ I do not know } & \multicolumn{2}{c|}{ Total } \\
\cline { 2 - 9 } & No. & $\%$ & No. & $\%$ & No. & $\%$ & No. & $\%$ \\
\cline { 2 - 9 } & 52 & 52 & 23 & 23 & 25 & 25 & 100 & 100 \\
\hline
\end{tabular}

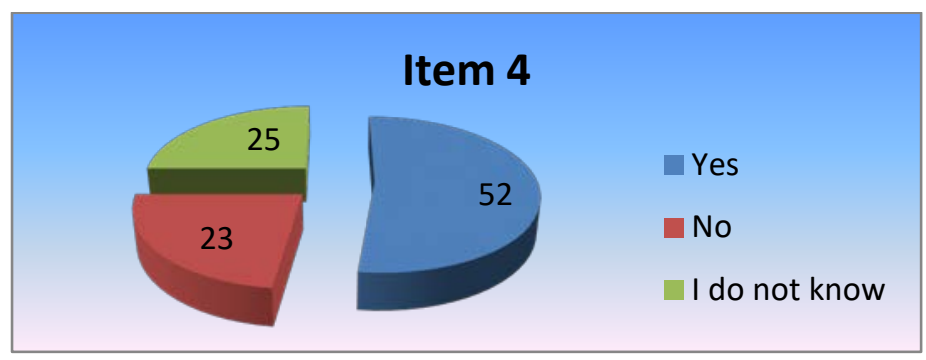

Graph 4. The percentage values of the data item 4 
The conciliatory role of physical activity or sport in conflicts is confirmed by the results obtained, with the positive answers reaching $52 \%$ in comparison to the negative ones (23\%) as well as to those corresponding to the "I do not know" answer, which have a representation of $25 \%$.

The fifth item is associated to the question: "Are you or were you part of a sports team?" The possible answers for this item are: Yes, No, I was part of a sports team. The data obtained in this item are presented in the table and graph 5.

Table 5. Values resulted from the processing of item 5

\begin{tabular}{|c|c|c|c|c|c|c|c|c|}
\hline \multirow{3}{*}{$\begin{array}{c}\text { Item } \\
5 .\end{array}$} & \multicolumn{2}{|c|}{ Yes } & \multicolumn{2}{c|}{ No } & \multicolumn{2}{c|}{$\begin{array}{c}\text { I was part of a } \\
\text { sports team }\end{array}$} & \multicolumn{2}{c|}{ Total } \\
\cline { 2 - 9 } & No. & $\%$ & No. & $\%$ & No. & $\%$ & No. & $\%$ \\
\cline { 2 - 9 } & 12 & 12 & 43 & 43 & 45 & 45 & 100 & 100 \\
\hline
\end{tabular}

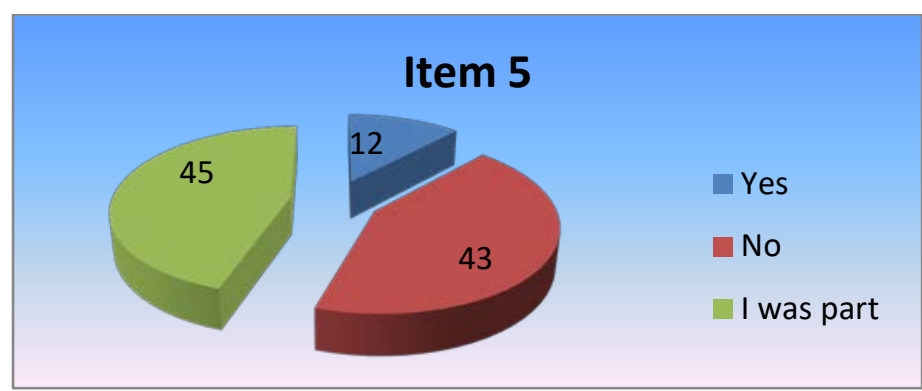

Graph 5. The percentage values of the data item 5

Concerning the membership of a sports team, $12 \%$ of the subjects are still affiliated with a team, $43 \%$ are not involved in any sports team and $45 \%$ were part of a sports team in the past. The small percentage of subjects still in a sports team, regardless of whether they are amateurs or engaging in performance sports, raises some questions about their perception of sport in general. Even if the perception is positive, practice shows that individuals do not get involved in organized sport as they should.

Item 6 focuses on the subjects' main reason for being involved in sports activities and is translated as: "Choose the main reason for which you participate in sports activities." The possible answers were: health, lifestyle, material gains, physical / beauty, relaxation and competition.

Table 6. Values of item 6

\begin{tabular}{|c|c|c|c|c|c|c|c|c|}
\hline \multirow{3}{*}{$\begin{array}{c}\text { Item } \\
6\end{array}$} & \multicolumn{2}{|c|}{ Health } & \multicolumn{2}{|c|}{ Lifestyle } & \multicolumn{2}{c|}{ Material gains } & \multicolumn{2}{c|}{ Total } \\
\cline { 2 - 9 } & No. & $\%$ & No. & $\%$ & No. & $\%$ & No. & $\%$ \\
\cline { 2 - 9 } & 30 & 30 & 14 & 14 & 3 & 3 & 100 & 100 \\
\hline
\end{tabular}


Table 7. Values of item 6 (continuation)

\begin{tabular}{|c|c|c|c|c|c|c|c|c|}
\hline \multirow{3}{*}{$\begin{array}{c}\text { Item } \\
6\end{array}$} & \multicolumn{2}{|c|}{$\begin{array}{c}\text { Physical/ } \\
\text { beauty }\end{array}$} & \multicolumn{2}{|c|}{ Relaxation } & \multicolumn{2}{c|}{ Competition } & \multicolumn{2}{c|}{ Total } \\
\cline { 2 - 9 } & No. & $\%$ & No. & $\%$ & No. & $\%$ & No. & $\%$ \\
\cline { 2 - 9 } & 22 & 22 & 21 & 21 & 10 & 10 & 100 & 100 \\
\hline
\end{tabular}

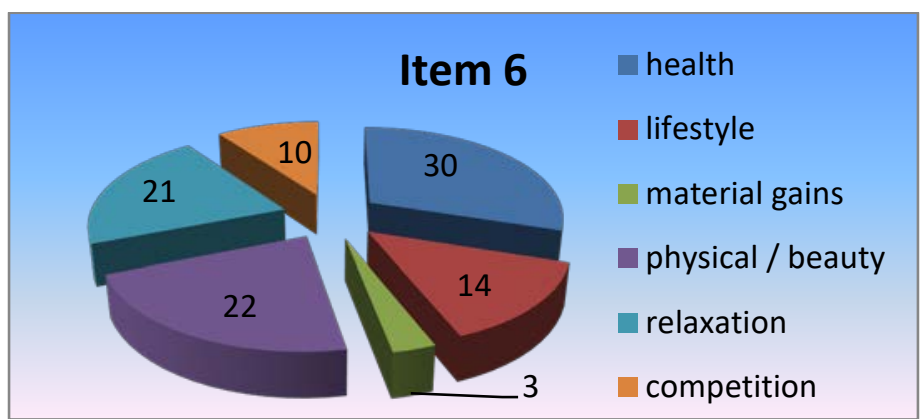

Graph 6. The percentage values of the data item 6

The results obtained from this item show that, for today's young people, the main reason for which they participate in sports activities is maintaining / improving their health (30\%), followed by close values related to improving physical condition or maintaining a beautiful body (22\%) and relaxation (21\%). Lifestyle is preferred as an answer for only $14 \%$ of the subjects, followed by participation in competitions with a proportion of $10 \%$, the last place being occupied by material gains with the $3 \%$.

The seventh item answers the question: "Do you think that by practicing different sports you have met new people?", and has three possible answers such as Yes, No, and I do not know. The results obtained are presented below in the table 8 and graph 7.

Table 8. Values resulted from the processing of item 7

\begin{tabular}{|c|c|c|c|c|c|c|c|c|}
\hline \multirow{2}{*}{$\begin{array}{c}\text { Item } \\
7 .\end{array}$} & \multicolumn{2}{|c|}{ Yes } & \multicolumn{2}{c|}{ No } & \multicolumn{2}{c|}{ I do not know } & \multicolumn{2}{c|}{ Total } \\
\cline { 2 - 9 } & No. & $\%$ & No. & $\%$ & No. & $\%$ & No. & $\%$ \\
\cline { 2 - 9 } & 59 & 59 & 28 & 28 & 13 & 13 & 100 & 100 \\
\hline
\end{tabular}

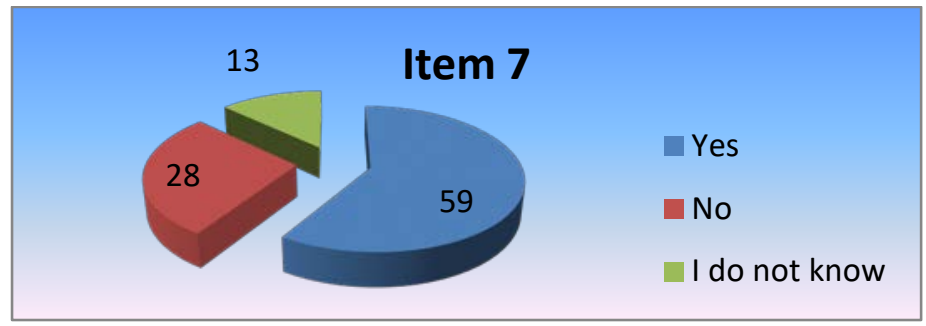

Graph 7. The percentage values of the data item 7 
Most of the respondents questioned in item 7 considered that by practising sports activities they had met new people (59\%), as compared to those who chose a negative answer, thus having a $28 \%$ response rate, and those who answered "I do not know", who represent $13 \%$ of all the people involved in the research group.

Item 8 was represented by the question: "Do you consider that practising physical exercise / sport is important for one's personal development?". In the case of this item, there were four possible answers, namely: Very important, Important, Unimportant and I do not know. The resulting data is presented in the table and graph below.

Table 9. Values resulted from the processing of item 8

\begin{tabular}{|c|c|c|c|c|c|c|c|c|c|c|}
\hline \multirow{2}{*}{$\begin{array}{c}\text { Item } \\
\text { 8. }\end{array}$} & \multicolumn{2}{|c|}{$\begin{array}{c}\text { Very } \\
\text { important }\end{array}$} & \multicolumn{2}{|c|}{ Important } & \multicolumn{2}{c|}{ Unimportant } & \multicolumn{2}{c|}{$\begin{array}{c}\text { I do not } \\
\text { know }\end{array}$} & \multicolumn{2}{c|}{ Total } \\
\cline { 2 - 10 } & No. & $\%$ & No. & $\%$ & No. & $\%$ & No. & $\%$ & No. & $\%$ \\
\cline { 2 - 11 } & 18 & 18 & 52 & 52 & 16 & 16 & 14 & 14 & 100 & 100 \\
\hline
\end{tabular}

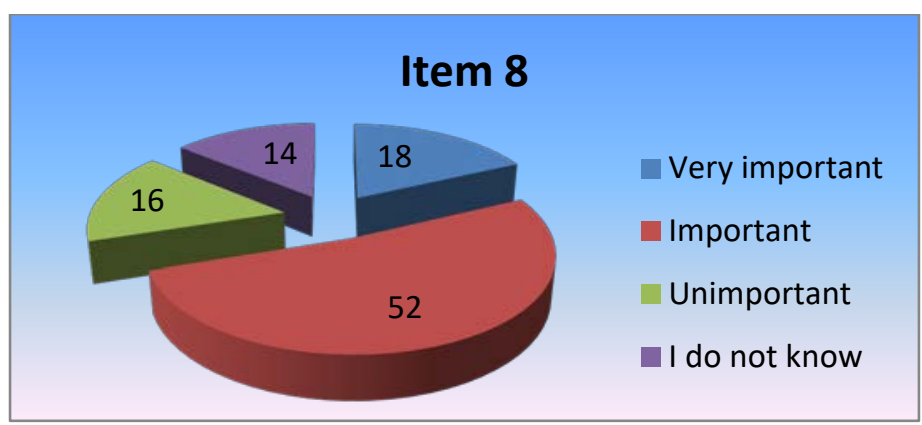

Graph 8. The percentage values of the data item 8

From the observation of the results obtained for this item, we distinguish the higher percentage (52\%) of answers that consider physical exercise / sport as being important for one's personal development, while $18 \%$ of the subjects rated it as "very important". Also, a percentage of $16 \%$ of the respondents rated this aspect as "unimportant" and only 14\% answered "I do not know". In a previous study similar results were obtained: $76 \%$ of the students considered helpful to practice a sport for their future, while $24 \%$ considered that it helps a little or not at all (Pop, 2014).

\section{Conclusions}

The research emphasises that the younger generation believes that by practising different sport activities they had met new people, highlighting the socialization factor of the researched phenomenon.

In the same context, practising sports is important for the young people's personal development, having a conciliatory role in certain conflicts, but it can also overcome social barriers. At the same time, we note that sports activities are 
important in everyday life for young people, but the majority of them do not regularly follow sports events (on TV or live).

However, the younger generation chooses as the main reason to participate in sports activities the improvement of health, followed by improvement of physical condition, maintaining a beautiful body and relaxation. Lifestyle was recorded only by $14 \%$ of the subjects, which indicates that university students are not aware of its importance.

Regardless of how physical activity is practiced, life without physical exercise should not exist, the benefits of these activities being far above certain inconveniences such as the time spent in such activities (more correctly the lack of necessary time), certain physical discomforts (muscle soreness), the risk of injuries or even lack of interest.

Based on the physical exercise chosen according to the particularities of individuals, an adequate effort-resting relation supplemented by a healthy diet, avoidance of harmful factors (smoking, alcohol, drugs etc.), weight management, all of which aim to extend the life expectancy of the population and keep it within good health limits.

\section{REFERENCES}

1. Bompa, T., 2001, Dezvoltarea calităţilor biomotrice - Periodizarea, Ediţie şi traducere în limba română, CNFPA, Edit. Ex Ponto, Bucureşti.

2. Bota, C., 2000, Ergofiziologie, Edit. Globus, Bucureşti.

3. Bota, C., 2002, Fiziologie generală. Aplicaţii la efortul fizic, Edit. Medicală, Bucureşti.

4. Cristea, E., 1990, Terapia prin mișcare la vârsta a treia, Edit. Medicală, București.

5. Dragan, I., 1982, Medicina spotiva, Editura Sport - Turism, Bucuresti.

6. Dumitru, Gh,, 1997, Sănătate prin sport pe înțelesul fiecăruia, Federația Română Sportul pentru Toți, Bucuresti.

7. Pop, C., 2014, Student's Satisfaction - An Indicator of Quality in Physical Education. Revista Romaneasca pentru Educatie Multidimensionala,Volume 6, Issue 1, p. 89. http://revistaromaneasca.ro/wp-content/uploads/2014/07/ REV_June2014_83to92.pdf

8. Suciu, A., Dumitru, Gh., 1999, Ghid pentru sănătate și condiție fizică, Federația Română Sportul pentru Toți, Bucuresti

9. https://dokumen.tips/documents/chestionar-sociologic-despre-sport.html

10. http://www.sport.pub.ro/activ_stiintifica_studenti/Sesii\%20stud\%202017/Mod el_cercetare_anchet\%C4\%83_chestionar.pdf

11. http://www.bpe.biz.pl/kts-k/ro/sport-4-all_ro/

12. https://freeonlinesurveys.com/s.asp?sid=33v96iz9itd9yau603528\#/0

13. https://semneletimpului.ro/sanatate/stil-de-viata/sport/cum-iti-schimbasportul-viata.html 